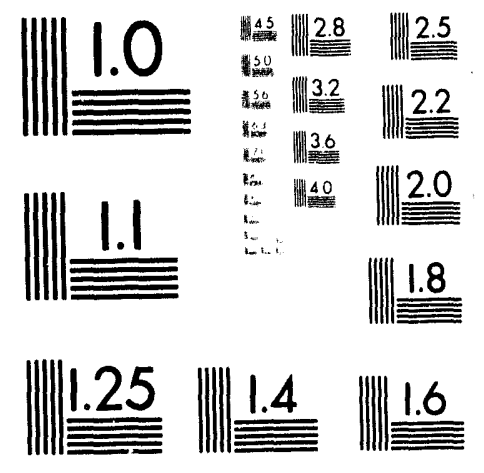



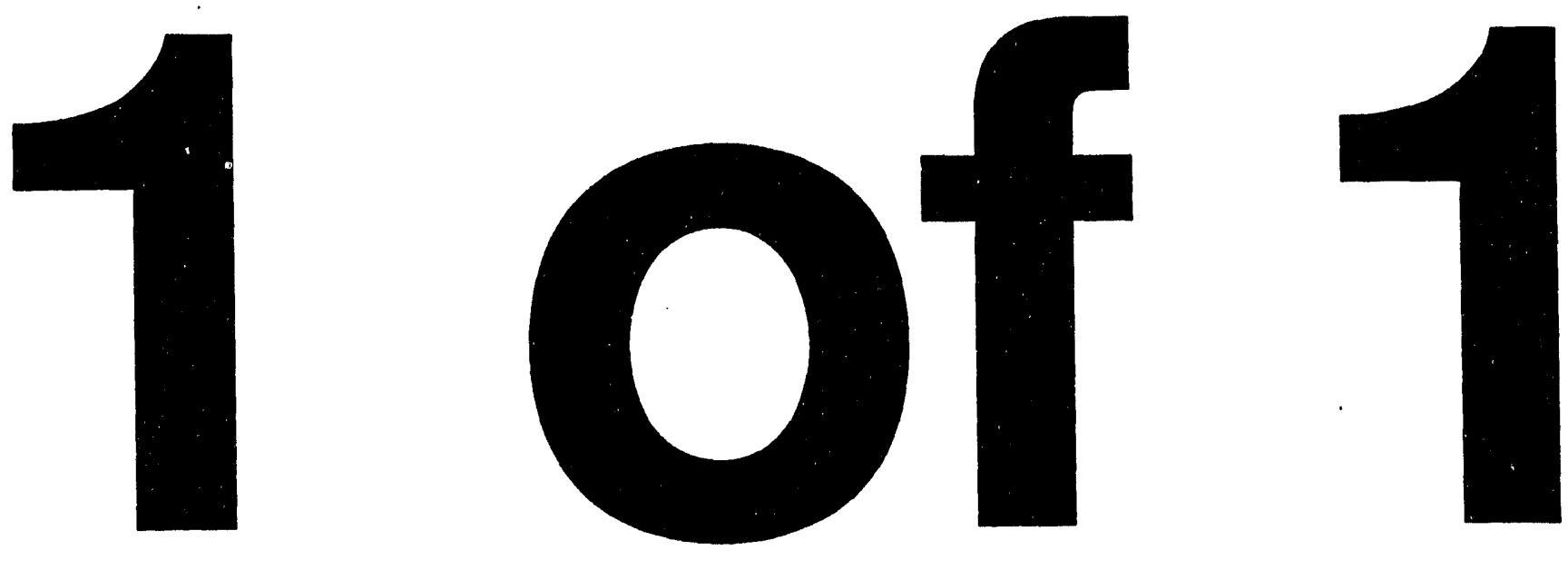
$\frac{3}{10.94862}$

PREPARED FOR THE U.S. DEPARTMENT OF ENERGY, UNDER CONTRACT DE-AC02-76-CHO-3073

PPPL-2960

UC-426
PPPL-2960

LOWER HYBRID CURRENT DRIVE AND ION BERNSTEIN WAVE HEATING EXPERIMENTS ON PBX-M

BY

S. BERNABEI AND THE PBX-M GROUP

FEBRUARY, 1994

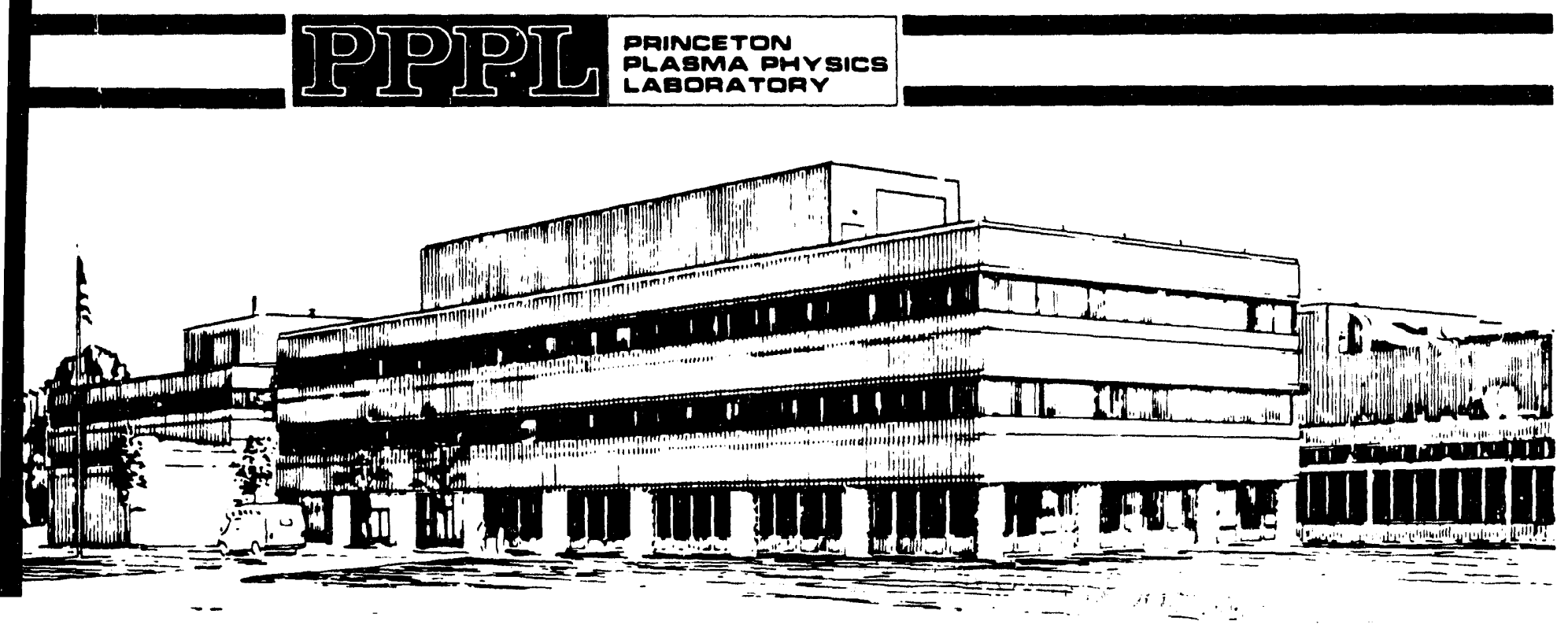




\section{NOTICE}

This report was prepared as an account of work sponsored by an agency of the United States Government. Neither the United States Government nor any agency thereof, nor any of their employees, makes any warranty, express or implied, or assumes any legal liability or responsibility for the accuracy, completeness, or usefulness of any information, apparatus, product, or process disclosed, or represents that its use would not infringe privately owned rights. Reference herein to any specific commercial produce, process, or service by trade name, trademark, manufacturer, or otherwise, does not necessarily constitute or imply its endorsement, recommendation, or favoring by the United States Government or any agency thereof. The views and opinions of authors expressed herein do not necessarily state or reflect those of the United States Government or any agency thereof.

\section{NOTICE}

This report has been reproduced from the best available copy. Available in paper copy and microfiche.

Number of pages in this report: 17

DOE and DOE contractors can obtain copies of this report from:

Office of Scientific and Technical Information

P.O. Box 62

Oak Ridge, TN 37831;

(615) $576-8401$.

This report is publicly available from the:

National Technical Information Service

Department of Commerce

5285 Port Royal Road

Springfield, Virginia 22161

(703) $487-4650$ 


\title{
Lower Hybrid Current Drive and Ion Bernstein Wave Heating Experiments on PBX-M.
}

\author{
S. Bernabei and the PBX-M group. \\ Princeton University, Plasma Physics Laboratory, Forrestal Campus \\ P. O. Box 451, Princeton, New Jersey 08543, USA
}

\begin{abstract}
.
This paper presents an overview of the experiments conducted on PBX-M to evaluate the feasibility and effect of current profile and pressure profile control on the plasma stability. Utilizing the inaccessibility of the Lower Hybrid waves, it has been possible to obtain a certain degree of power deposition localization and offaxis current drive. The effect of fast electron diffusion has been studied and found not to be a limiting factor; consequently, the current profile has been modified in a non-transient manner. More serious is the destabilization of global MHD modes, due to the change of the current profile, which can lead to disruption or to a rapid radial redistribution of the fast electron population. Experiments with Ion Bernstein wave heating have shown that power can be deposited off-axis and that the ion temperature can be modified locally. Application of IBW into a strongly Neutral Beam (NBI) heated H-mode plasma causes a substantial increase of thermal and particle confinement in the core of the plasma: this produces a localized bootstrap current sufficient to significantly raise the value of $q(0)$. We propose to refer to this condition as the $\mathrm{CH}$-mode (or Core High-confinement mode).
\end{abstract}

\subsection{Introduction.}

The experimental program of the PBX-M tokamak has been devoted to the systematic study of the improvements in plasma stability obtainable by controlling the current profile and the pressure profile. In particular, these improvements are targeted at demonstrating the feasibility of achieving full-volume "second stability" again: $t$ ballooning modes.

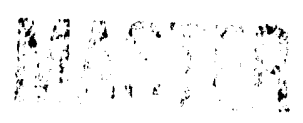


Lower Hybrid Current Drive (LHCD) is employed as a means of modifying the current profile; the system consists of a $2 \mathrm{MW}$ source power at $4.6 \mathrm{GHz}$, with a pulse duration of 0.5 seconds. Power is coupled through two arrays, each with 32 waveguides that can be independently phased: the system is equipped with a fast response phase shifter capable of a rate of change of $20 \% \mathrm{msec}$. Ion Bernstein wave (IBW) heating is used to modify the pressure profile: the system consists of two antennas capable of $1 \mathrm{MW}$ each at a frequency between $40 \mathrm{MHz}$ and $80 \mathrm{MHz}$.

\subsection{CURRENT PROFILE MODIFICATION WITH LOWER HYBRID WAVES.}

\subsection{Power deposition control.}

There are two fundamental problems associated with the control of the current profile with LHCD: first, it is essential to have the ability of controlling the location of the damping of the $\mathrm{rf}$ power, and second, once the fast electron tail is formed, it is important that the radial transport does not affect significantly the localization. It is well known that the power deposition in plasmas hot enough for the wave to damp on the first pass can be controlled by launching a narrow $n_{\|}$ spectrum and varying the $\mathrm{n}_{\|}$launched. In the initial PBX-M experiment, the electron temperature was too low for the wave to damp on the first pass, but we were able to obtain a good degree of localization by taking advantage of the limit in penetration imposed by accessibility. Figure 1 shows the comparison between the location of the damping and the maximum accessibility as functions of the peak launched $n_{\|}\left(n_{\| 0}\right)$. The location of the damping is measured during pulsed operation of the RF power: the hard $x$-ray emission is Abel-inverted and the location where the signal has the maximum variation at the turn-on of the power is determined (Jones [1]). In this manner the effect of diffusion is minimized. An example of such an $x$-ray profile is given in Fig. 4 . The accessibility curve has been obtained from the LSC ray tracing code (Ignat [2]), using experimental values for the plasma parameters: the value plotted corresponds to the first 
approach of the wave to the center, which leaves the value of $n_{\|}$approximately unchanged, as in the example of Fig. 2. Usually after this first pass the $n_{\|}$is upshifted: in this case the wave is confined further out in the radius and the damping is rather insensitive to the variation of $\mathrm{n}_{\| 0}$, but remains spatially localized because of ray motion constraints (Kupfer [3], Paoletti [4], Takahashi [5]). It has also been verified that the power deposition is related to wave accessibility by varying the magnetic field, with penetration increasing with the field.

\subsection{Fast electron diffusion.}

As stated earlier, the achievemnet of power localization is of little use for current profile control if diffusive transport spreads the fast electrons across the plasma radius. In general there are two mechanisms for diffusion across the field lines: normal diffusion and enhanced diffusion or scattering due to MHD modes.

Making extensive use of the images produced by the 2-D hard x-ray camera, we have been able to demonstrate that normal diffusion occurs on a scale length of about $7 \mathrm{~cm}$ (compared to the minor radius of $30 \mathrm{~cm}$ ), while enhanced diffusion due to MHD modes occurs on scale lengths at least a factor of 4 longer. This can be readily seen in the hard $\mathrm{x}$-ray images: in the former condition, an off-axis deposition can be produced and maintained throughout the discharge, while in the latter condition it can be completely lost during strong MHD activity. In MHDquiescent plasmas we have been able to measure a lower and $a$ upper limit to the diffusion following methods developed by S. Jones (Jones [6]). One method uses a Fokker-Planck model with the Stevens-von Goeler (Stevens [7] ) x-ray code: we compute a $2 \mathrm{D}$ image for the hard $\mathrm{x}$-ray emission, using the experimentallyderived absorbed power profile described in 2.1 and an assumed effective diffusion constant $D^{*}$. We then compare the simulated image with the experimental image and iterate the process using different values of $\mathrm{D}^{*}$ until a best fit is found.

The result of all these methods indicate that $1.1 \mathrm{~m}^{2} / \mathrm{sec} \leq \mathrm{D}^{*} \leq 1.7$ $\mathrm{m}^{2} / \mathrm{sec}$ (for electrons with velocities equal to the injected wave speed), 
implying that the collisional slowing down time is shorter than the diffusion time by about a factor 8 . Assuming that magnetic fluctuations are responsible for the radial diffusion, Fokker-Planck modeling with the Giruzzi code (Giruzzi [8]) has also been used, and a good match has been obtained for values of $\delta B / B$ $=3.8 \times 10-4$, which is consistent with estimates from various tokamaks.

\subsection{Current profile modification and MHD stability.}

Figure 3 shows the effect of $270 \mathrm{~kW}$ of RF power on the sawtooth behavior: the inversion radius shrinks inward and the sawteeth are suppressed after $\sim 200$ msec. To evaluate the changes in current and q profiles, we used the equilibrium reconstruction (Paoletti [9]) with the magnetic field pitch angle profile obtained from the Motional Stark Effect diagnostic (Levinton [10]). Figure 4 shows the radial profile of $q$ and the radial profile of the Abel-inverted hard $\mathrm{x}$-ray emission: we note that, in agreement with the sawteeth behavior, $q(0)$ rises to around 1.0 and the profile flattens. Note also that the current driven by the rf-waves seems located between the rational surfaces $q=1$ and $q=3 / 2$; it is interesting to see that, from the soft $\mathrm{x}$-ray (SXR) array, an $\mathrm{m}=1$ mode gradually disappears, while a weak $m=3 / 2$ grows. In this particular case, the weak MHD activity has little effect on the fast electron radial distribution; in cases at higher $\mathrm{rf}$ power or lower density, when the modification of the current profile is larger and more sudden, the MHD mode can grow and possibly lock, causing a small disruption and a rapid radial broadening of the electron profile. In some instances we have been able to avoid this situation by adding neutral beam power to the discharge (Bernabei [11]): in this situation the value of $q(0)$ increased to levels above 1.0. The $\mathrm{x}$-ray emission, and hence the RF driven current profile, remained localized offaxis for 2-3 times the magnetic diffusion time scale and no MHD activity was detected.

\subsection{ION BERNSTEIN WAVE HEATING.}

\subsection{IBW Heating.}

Heating experiments were performed at 47 and $54 \mathrm{MHz}$ at 12 and $14 \mathrm{kG}$, 
corresponding to the $5 \Omega_{\mathrm{D}}$ resonance near the plasma center. Figure 5 shows the increase of ion temperature measured with charge exchange recombination spectroscopy. The shaded area corresponds to the ray tracing calculation of the power deposition: in correspondence to it, the ion temperature profile has a steeper gradient. An analysis of the time variation of the ion temperature increase has shown that the the power absorption is well localized at an off-axis radius (Tighe [12]): this leads to the possibility of modifying the pressure profile with IBW heating.

3.2 Density peaking, suppression of sawtooth and ELM activity.

A strong density peaking has been observed during application of IBW power to the plasma. The phenomenology of this density peaking is the same for an Ohmic or NBI target plasma: it begins with an increase over the whole density profile, which progressively changes into a centrally-localized peaking. Figure 6 presents overlays of electron density profiles against major radius, $n_{e}(R)$, at various times during the discharge, for IBW alone (a) and for IBW and NBI plasmas (b). The resulting peaking parameters are similar for $\mathrm{IBW}+\mathrm{OH}$ and IBW + NBI plasmas. The electron temperature has a slight increase in the center, therefore the pressure profile becomes very peaked and produces a significant bootstrap current (LeBlanc [13]). The increase of thermal and particle confinement in the core supports the IBW induced poloidal shear flow model for creating the $\mathrm{H}$-mode-like barrier in the core region (Core $\mathrm{H}$-mode). The peaked profile (and the CH-mode) were thus far observed only in the resonant heating regime.

Figure 7 shows the comparison between the temporal evolution of the discharge of Fig. 6(b), which has a long IBW pulse (black line), and one with a short pulse (gray line). NBI power of $2 \mathrm{MW}$ is applied from 360 to $690 \mathrm{~ms}$ (not shown); $0.3 \mathrm{MW}$ IBW is applied from 460 to $680 \mathrm{~ms}$ (bottom panel); the short pulse lasts less than $40 \mathrm{~ms}$ and does not reach full RF power. For the purpose of this discussion, we will assume that the effect of the short $\mathrm{RF}$ pulse is negligible and 
refer to these two discharges as being with and without IBW. We can see (top panel) that, except for breaks associated to MHD activity seen for the non-IBWH case, the line integrated densities, $\mathrm{n}_{\mathrm{e}} \mathrm{l}$, for the discharges overlay well. On the other hand, the evolution of the density profile differs as shown in Fig. 6(b) and it is substantiated by the soft $\mathrm{x}$-ray emission traces at the center, $\mathrm{SXR}_{0}$, and at half minor radius, $\mathrm{SXR}_{\mathrm{a} / 2}$. It can be seen that for times larger than $580 \mathrm{~ms}$, the central density obtained with NBI/IBW is significantly larger than that of the NBI discharge. At half of the minor radius the situation is reversed; the density with NBI/IBW is smaller than with NBI. IBW modifies the trend of the neutron rate, which normally decreases with the onset of the H-mode: for times greater than $600 \mathrm{~ms} \mathrm{~S}_{\mathrm{n}}$ increases. This behavior results from the active density peaking (due to IBW) and from improved confinement achieved in the core region. Stabilization of sawtooth and ELM activity is associated with the density peaking. The last sawtooth with IBW is observed at $560 \mathrm{~ms}$, while the NBI-only discharge exhibits sawtooth and giant ELM activity until the end. The $\mathrm{D}_{\alpha}$ traces show that both discharges entered the $\mathrm{H}$-mode at $\sim 420 \mathrm{~ms}$. The $\mathrm{D}_{\alpha}$ temporal behavior differs shortly after the application of the RF pulse. During IBW, the "DC" level of the $\mathrm{D}_{\alpha}$ signal increases until a large event at $\sim 600 \mathrm{~ms}$, after which the $\mathrm{D}_{\alpha}$ decreases. The small ELM activity observed for times earlier than $600 \mathrm{~ms}$ suggests that the discharge is still in the $\mathrm{H}$-mode. During neutron production saturation, highfrequency MHD activity (reminescent of TAE mode excitation), not visible on Fig. 7 , is present. While for operational reasons the target plasmas had different cross-section shapes (slightly elongated for Ohmic and bean-shaped for NBI ), the influence of cross-sectional shaping on density by peaking has not been studied.

\subsection{CONCLUSION}

Current profile control with LHCD can be achieved by taking advantage of the limit in accessibility of the waves. The modification produced by the RF current can be maintained in spite of fast electron diffusion: we have experimentally determined a low and a high value for the effective diffusion constant. We have given an example of the rich MHD phenomenology which arises from modifying the current profile, and of the correlation between wave 
damping and MHD modes. An extensive study is necessary to arrive at a situation where the current profile can be modified without destabilizing MHD modes. With IBW, we have demonstrated the capability of modifying the pressure profile. IBW also enhances the confinement in the core region, which results in very peaked density and pressure profiles. The strong pressure gradient produces bootstrap currents sufficient to have a significant effect on $q_{0}$.

\section{AKNOWLEDGMENT}

This work was supported by the U. S. Department of Energy, Contract No. DEAC02-76CHO-3073.

\section{REFERENCES}

[1] S. Jones, Bull. Am. Phys. $\underline{38}, 10$ (Nov. 1993) invited paper 5I3, p. 1985

[2] D. Ignat et al, Princeton Plasma Physics Laboratory report PPPL-2929 (1993), also submitted to Nucl. Fus.

[3] K. Kupfer and D. Moreau, Nucl. Fusion 32, (1992) 1845

[4] F. Paoletti et aì. MIT report PFC/JA-93-22, also submitted to Nucl. Fus.

[5] H.Takahashi et al., Proc. 20th EPS Conf. on Controlled Fusion and Plasma Physics (Lisbon,1993)Vol 17C, p.III-901

[6] S. Jones et al., Plasma Phys. Controlled Fusion 35 (1993) 1003-1017

[7] J. Stevens, S. von Goeler et al., Nucl. Fusion 25 (1985) 1529

[8] G. Giruzzi, Plasma Phys. Controlled Fusion $\underline{35}$, (1993) A123

[9] F. Paoletti et al., Proc. of Tenth Topical Conf. on RF Power in Plasmas, (Boston, Mass. 1993), AIP Conf. Proc. 289 (New York 1993) 131.

[10] F. Levinton et a", Phys. Rev, Lett. 63, (1989) 2060

[11] S. Bernabei et al., Phys. Fluids B $\underline{5}$ (7), (1993) 2562

[12] W. Tighe et al., Proc. 20th EPS Conf. on Controlled Fusion and Plasma Physics (Lisbon,1993)Vol 17C, p.III-969

[13] B. LeBlanc et al., to be submitted to Phys. Fluids B

[14] H. Biglari et al., Proc. of Ninth Topical Conf. on RF Power in Plasmas (Charleston, 1991), AIP Conf. Proc. 244 (New York, 1992) 376. 


\section{FIGURE CAPTIONS.}

Fig.1 Accessibility of the wave versus the peak value of the $n_{\|}$spectrum launched, for a deuterium plasma with $\mathrm{n}_{\mathrm{eo}}=3.4 \times 10^{13} \mathrm{~cm}^{-3}, \mathrm{~B}_{\mathrm{t}}=17 \mathrm{kG}$ and $\mathrm{I}_{\mathrm{p}}=$ $180 \mathrm{kA}$. Circles correspond to the radial position of the maximum variation of the inverted emissivity of the hard $x$-rays.

Fig. 2 Radial variation of $n_{\|}$for the launched value of 3.1 . The abscissa is the square root of the normalized poloidal flux; the dotted line corresponds to $\mathrm{v}_{\text {phase }} / \mathrm{v}_{\text {thermal }} \approx 3.5$.

Fig. 3 Sawtooth inversion radius versus time. Conditions are: $\mathrm{n}_{\mathrm{eo}}=3.710^{13}$ $\mathrm{cm}^{-3}, \mathrm{I}_{\mathrm{p}}=177 \mathrm{kA}, \mathrm{B}_{\mathrm{t}}=17 \mathrm{kG}$.

Fig. 4 q-profile for the discharge with conditions as in Fig. 2, compared with a similar discharge without LHCD; broken line is the inverted hard $x$-ray emissivity.

Fig. 5 Ion temperature profile with and without IBW. The calculated IBW power deposition is also shown.

Fig. 6 Density profile with application of IBW power in (a) OH discharge, and (b) $\mathrm{OH}+\mathrm{NBI}$ discharge. In the first case the IBW power is applied from $\mathrm{t}=350$ msec to $\mathrm{t}=690 \mathrm{msec}$ and in the second from 460 to $690 \mathrm{msec}$, while NBI power is from 360 to $690 \mathrm{msec}$.

Fig. 7 Density peaking with application of IBW power, as seen in the differen behavior of the soft $\mathrm{x}$-ray emission at the center $\left(\mathrm{SXR}_{0}\right)$ and at mid-radius $\left(\mathrm{SXR}_{\mathrm{a} / 2}\right)$.

$\mathrm{n}_{\mathrm{e}} \mathrm{l}=\mathrm{n}_{\mathrm{e}} \times 60, \mathrm{~S}_{\mathrm{n}}=$ neutron flux, $\mathrm{B}_{\mathrm{t}}=15 \mathrm{kG}, \mathrm{I}_{\mathrm{p}}=250 \mathrm{kA}, \mathrm{P}_{\mathrm{IBW}}=300 \mathrm{~kW}, \mathrm{P}_{\mathrm{NBI}}=2$ MW. 


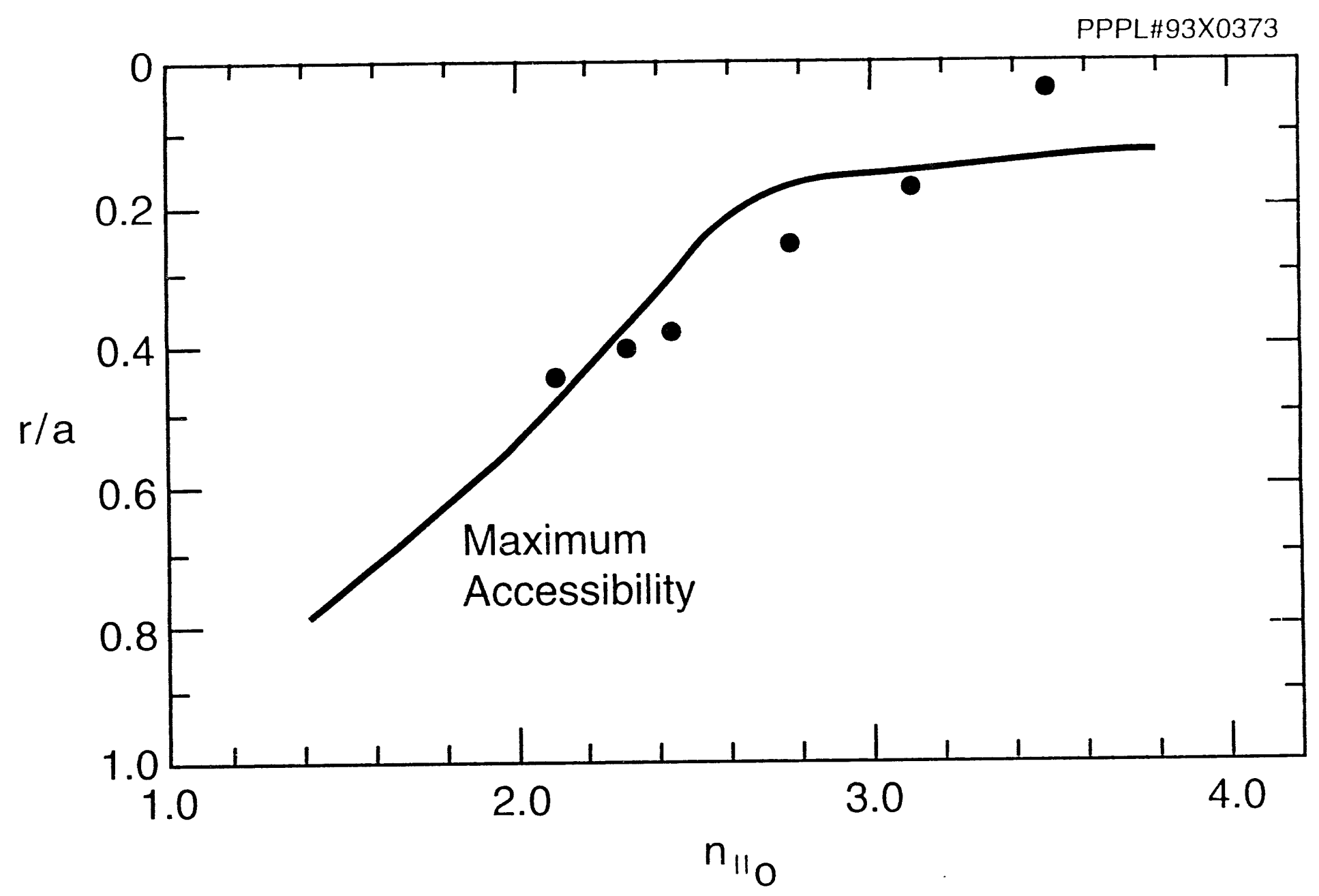


S. Bernabei fig. 2

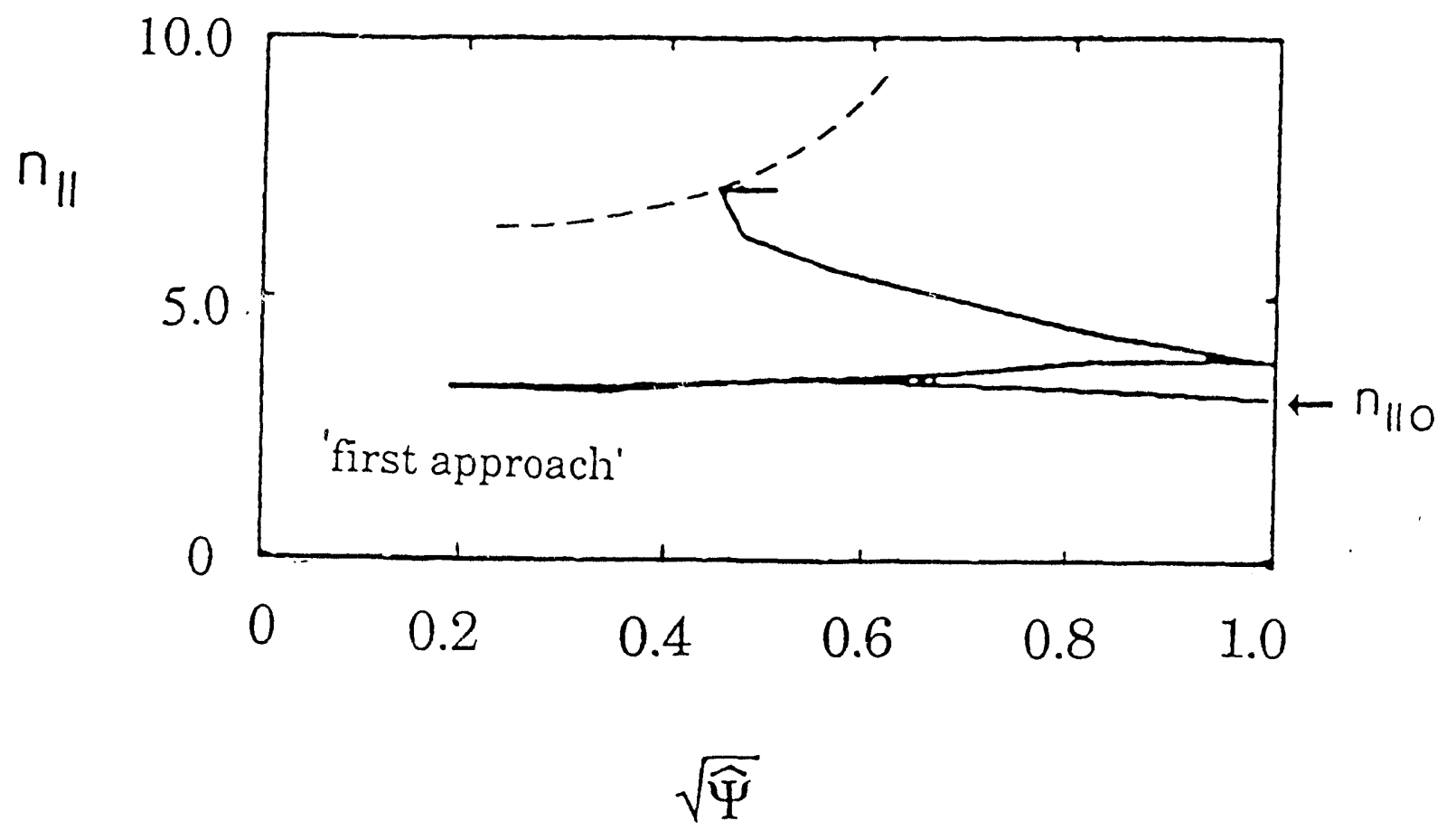


(गวsu) 7

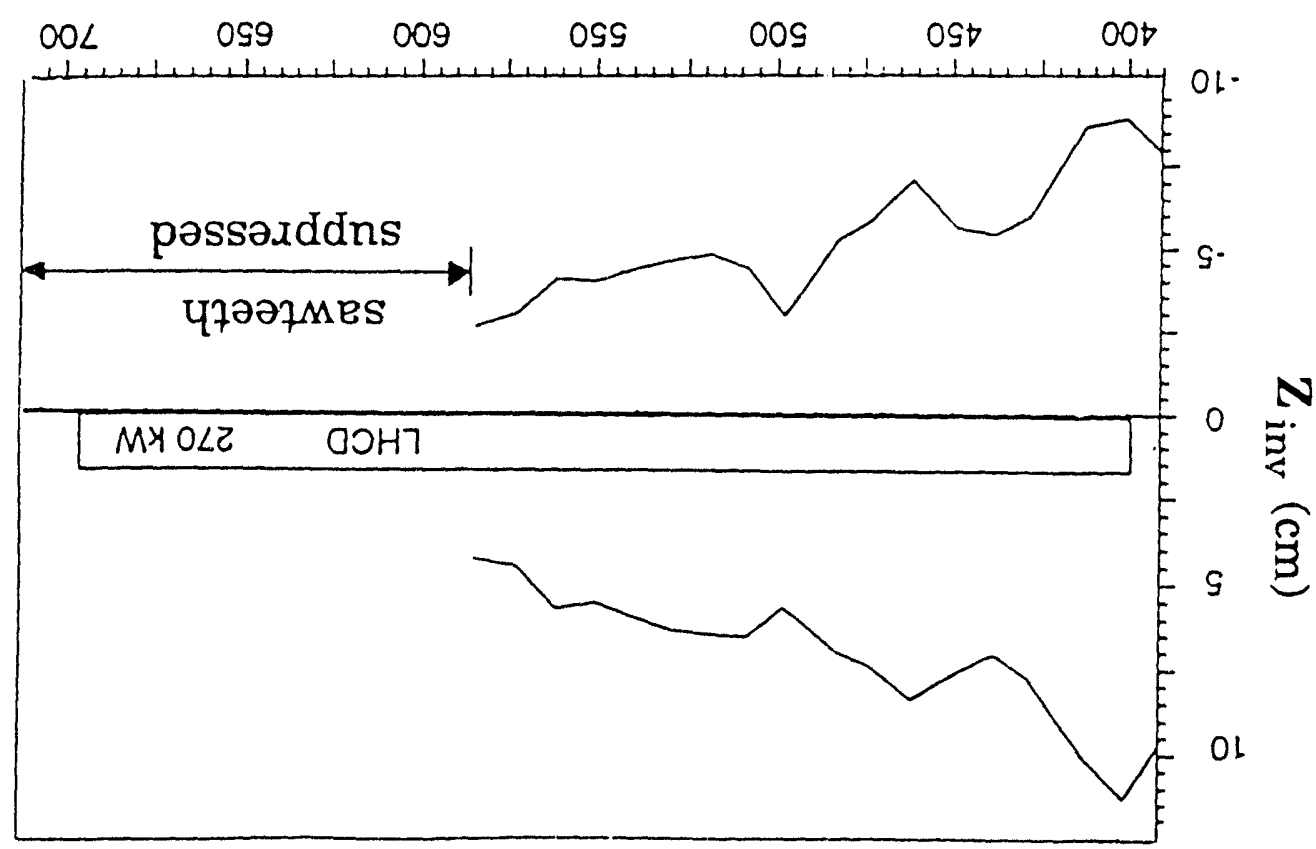


S. Bernabei fig. 4

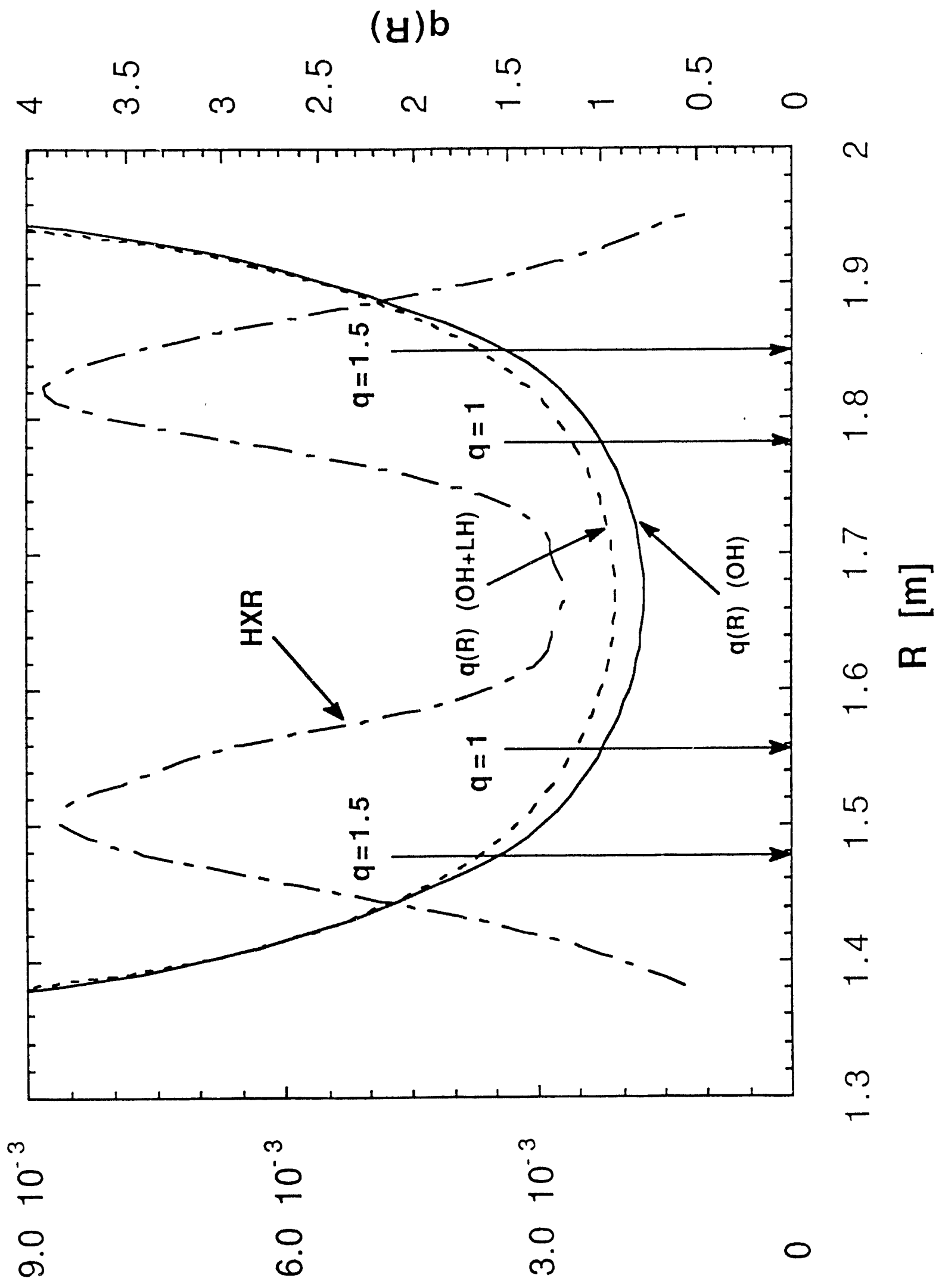

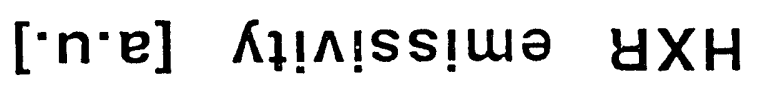




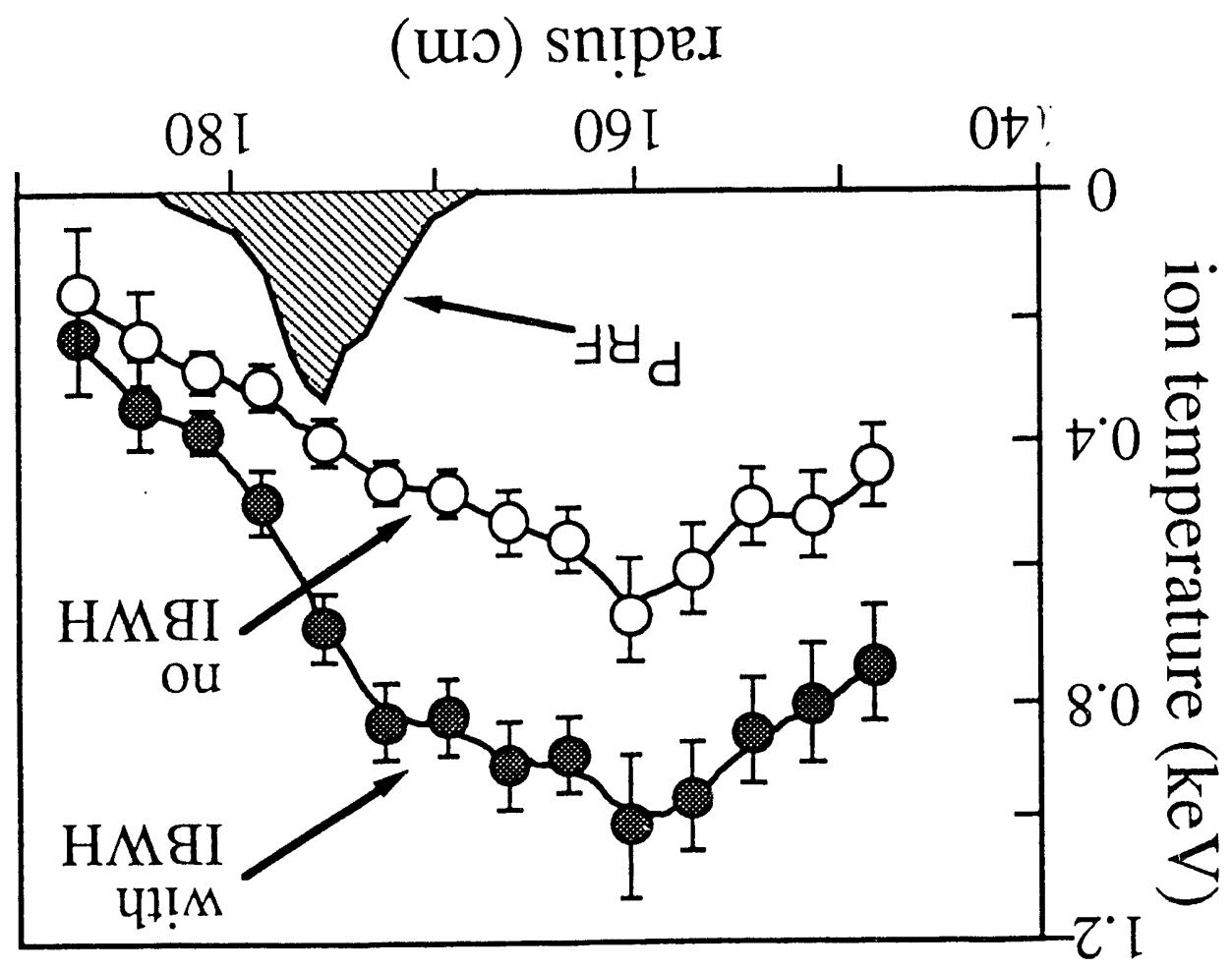



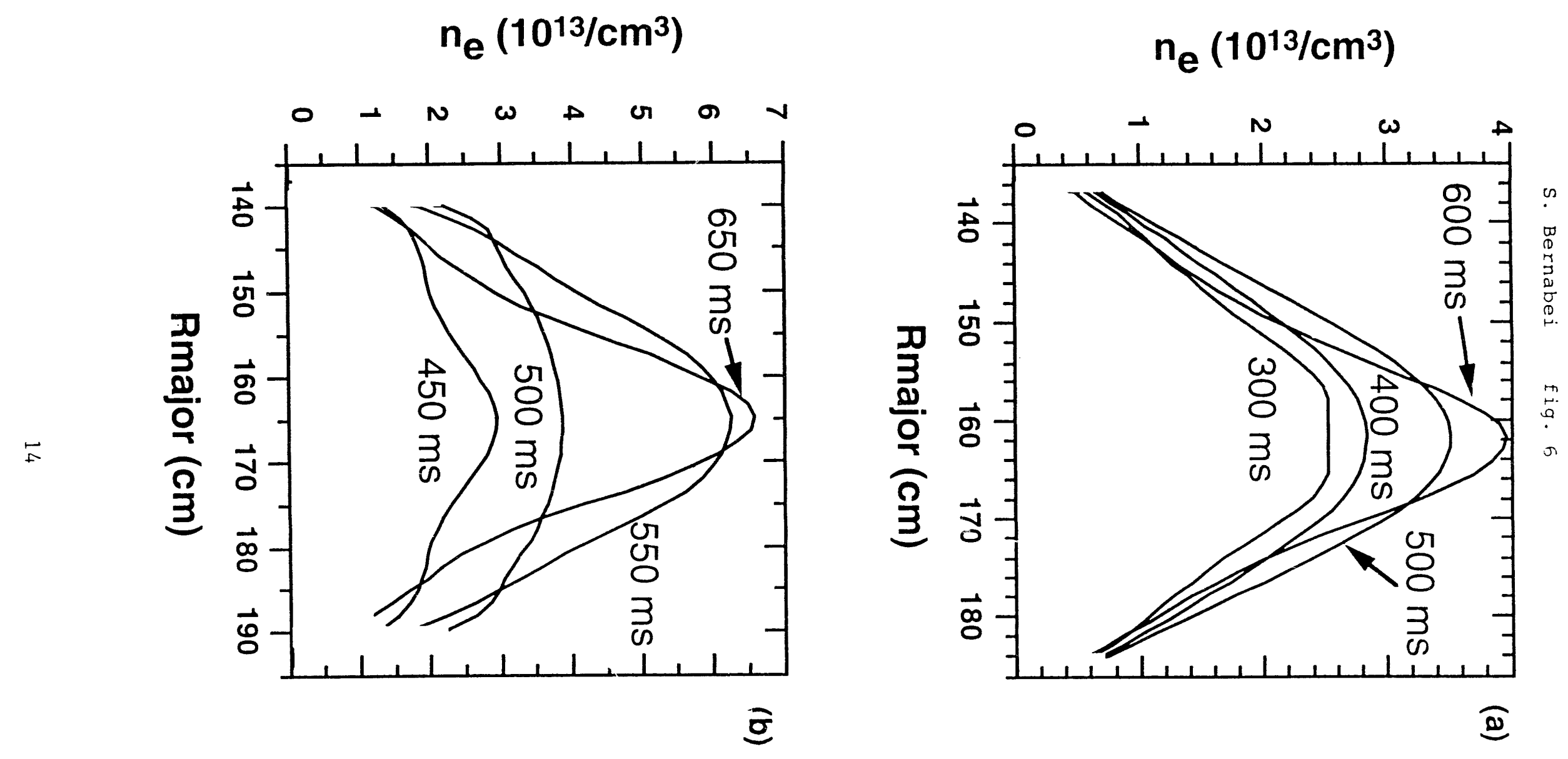
S. Bernabei fig. 7

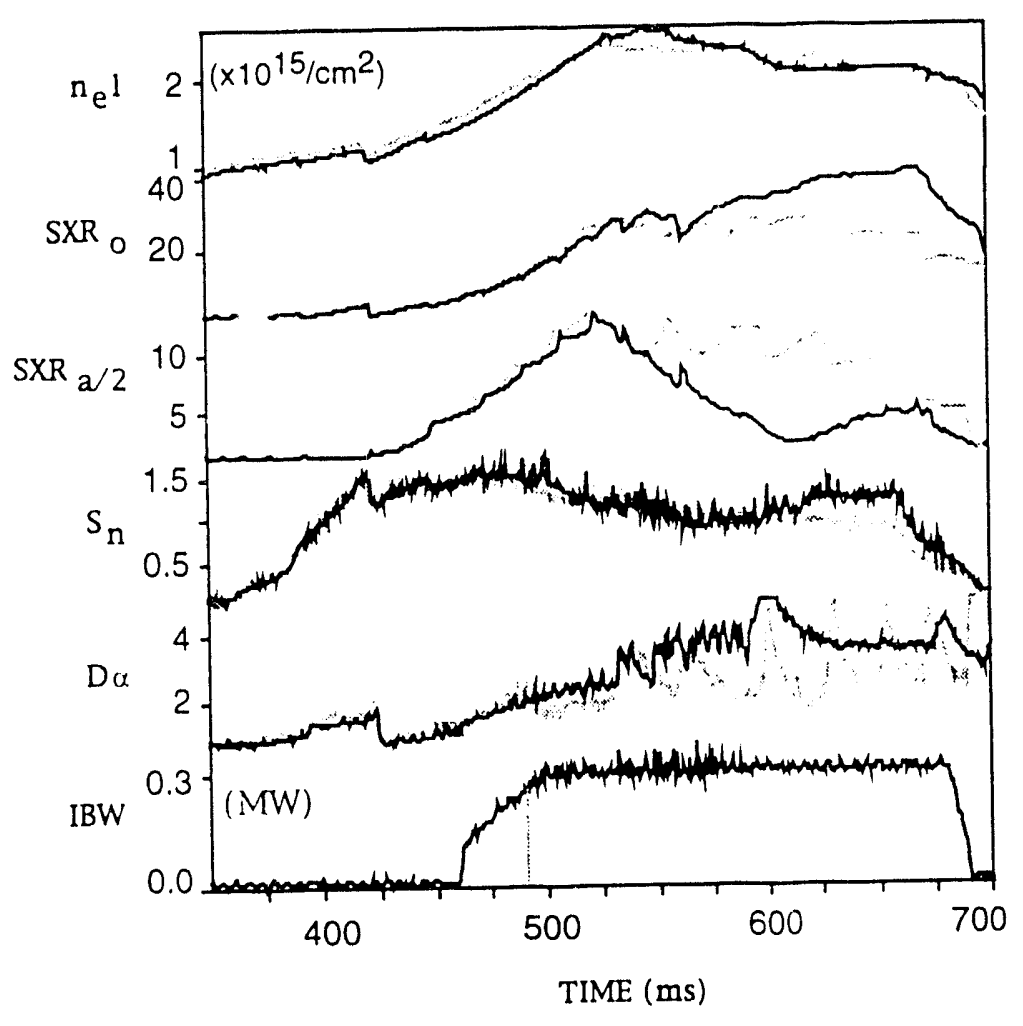


Dr. F. Paoloni, Univ. of Wollongong, AUSTRALIA

Prof. M.H. Brennan, Univ. of Sydney, AUSTRALIA

Plasma Research Lab., Australian Nat. Univ., AUSTRALIA

Prof. I.R. Jones, Flinders Univ, AUSTRALIA

Prof. F. Cap, Inst. for Theoretical Physics, AUSTRIA

Prof. M. Heindler, Institut für Theoretische Physik, AUSTRIA

Prof. M. Goossens, Astronomisch Instituut, BELGIUM

Ecole Royale Militaire, Lab. de Phy. Plasmas, BELGIUM

Commission-European, DG. XII-Fusion Prog., BELGIUM

Prof. R. Bouciqué, Rijksuniversiteit Gent, BELGIUM

Dr. P.H. Sakanaka, Instituto Fisica, BRAZIL

Prof. Dr. I.C. Nascimento, Instituto Fisica, Sao Paulo, BRAZIL Instituto Nacional De Pesquisas Espaciais-INPE, BRAZIL Documents Office, Atomic Energy of Canada Ltd., CANADA

Ms. M. Morin, CCFMTokamak de Varnnnes, CANADA

Dr. M.P. Bachynski, MPB Technologies, Inc., CANADA

Dr. H.M. Skarsgard, Univ. of Saskatchewan, CANADA

Prol. J. Teichmann, Univ. of Rintreal, CANADA

Prof. S.R. Sreenivasan, Univ. of Calgary, CANADA

Prot. T.W. Johnston, INRS-Energie, CANADA

Dr. R. Bolton, Centre canadien de fusion magnétique, CANADA

Dr. C.R. James, Univ. of Alberta, CANADA

Dr. P. Lukác, Komenského Universzita, CZECHO-SLOVAKIA

The Librarian, Culham Laboratory, ENGLAND

Library, R61, Ruthertord Appleton Laboratory, ENGLAND

Mrs. S.A. Hutchinson, JET Library, ENGLAND

Dr. S.C. Sharma, Univ. of South Pacific, FIJI ISLANDS

P. Mähönen, Univ. of Helsinki, FINLAND

Prot. M.N. Bussac, Ecole Polytechnique, FRANCE

C. Mouttet, Lab. de Physique des Milieux lonisés, FRANCE

J. Radet, CEN/CADARACHE - Bat 506, FRANCE

Prof. E. Economou, Univ, of Crete, GREECE

Ms. C. Rinni, Univ. of loannina, GREECE

Preprint Library, Hungarian Academy of Sci., HUNGARY

Dr. B. DasGupta, Saha Inst. of Nuclear Physics, INDIA

Dr. P. Kaw, Inst. for Plasma Research, INDIA

Dr. P. Rosenau, Israel Inst. of Technology, ISRAEL

Librarian, International Center for Theo Physics, ITALY

Miss C. De Palo, Associazione EURATOM-ENEA, ITALY

Dr. G. Grosso, Istituto di Fisica del Plasma, ITALY

Prof. G. Rostangni, Istituto Gas lonizzati Del Cnr, ITALY
Dr. H. Yamato, Toshiba Res \& Devel Center, JAPAN

Prof. I. Kawakami, Hiroshima Univ., JAPAN

Prot. K. Nishikawa, Hiroshima Univ., JAPAN

Librarian, Naka Fusion Research Establishment, JAERI, JAPAN

Director, Japan Atomic Energy Research Inst., JAPAN

Prot. S. Itoh, Kyushu Univ., JAPAN

Research Info. Ctr., National Instit. for Fusion Science, JAPAN

Prof. S. Tanaka, Kyoto Univ., JAPAN

Library, Kyoto Univ., JAPAN

Prot. N. Inove, Univ. of Tokyo, JAPAN

Secretary, Plasma Section, Electrotechnical Lab., JAPAN

S. Mori, Technical Advisor, JAERI, JAPAN

Dr. O. Mitarai, Kumamoto Inst. of Technology, JAPAN

Dr. G.S. Lee, Korea Basic Sci. Ctr., KOREA

J. Hyeon-Sook, Korea Atomic Energy Research Inst., KOREA

D.I. Choi, The Korea Adv. Inst. of Sci. \& Tech., KOREA

Prof. B.S. Liley, Univ. of Waikato, NEW ZEALAND

Inst of Physics, Chinese Acad Sci PEOPLE'S REP. OF CHINA

Library, Inst. of Plasma Physics, PEOPLE'S REP OF CHINA

Tsinghua Univ. Library, PEOPLE'S REPUBLIC OF CHINA

7. Li, S.W. Inst Physics, PEOPLE'S REPUBLIC OF CHINA

Prof. J.A.C. Cabral, Instituto Superior Tecnico, PORTUGAL

Prof. M.A. Hellberg, Univ. of Natal, S. AFRICA

Prof. D.E. Kim, Pohang Inst. of Sci. \& Tech., SO. KOREA

Prof. C.I.E.M.A.T, Fusion Division Library, SPAIN

Dr. L. Stenfio, Univ. of UMEA, SWEDEN

Library, Royal Inst. of Technology, SWEDEN

Prof. H. Wilhelmson, Chalmers Univ. of Tech., SWEDEN

Centre Phys. Des Plasmas, Ecole Polytech, SWITZERLAND

Bibliotheek, Inst. Voor Plasma-Fysica, THE NETHERLANDS

Asst. Prot. Dr. S. Cakir, Middle East Tech. Univ., TURKEY

Dr. V.A. Glukhikh,Sci. Res. Inst. Electrophys! Apparatus, USSR

Dr. D.D. Ryutov, Siberian Branch of Academy of Sci., USSR

Dr. G.A. Eliseev, I.V. Kurchatov Inst., USSR

Librarian, The Ukr.SSR Academy of Sciences, USSR

Dr. L.M. Kovrizhnykh, Inst. of General Physics, USSR

Kernforschungsanlage $\mathrm{GmbH}$, Zentralbibliothek, W. GERMANY

Bibliothek, Inst. Für Plasmatorschung, W. GERMANY

Prof. K. Schindler, Ruhr-Universitát Bochum, W. GERMANY

Dr. F. Wagner, (ASDEX), Max-Planck-Institut, W. GERMANY

Librarian, Max-Planck-Institut, W. GERMANY 

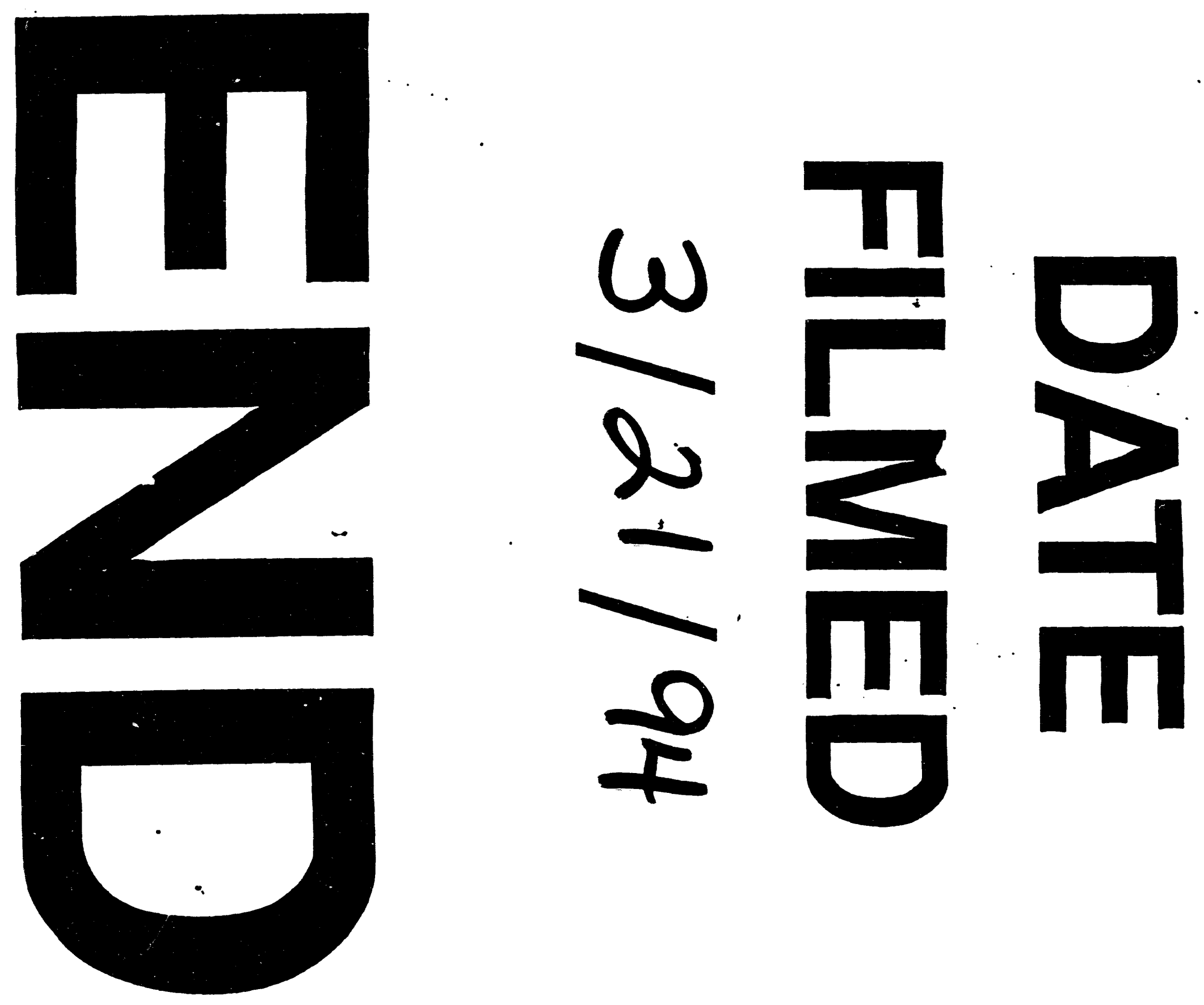


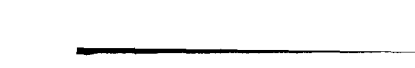

